\title{
Częściowa dezaktywacja wszczepialnego kardiowertera-defibrylatora u kresu życia
}

\section{Selective deactivation of implantable cardioverter-defibrillator at the end-of-life}

\author{
Tomasz Grądalski, Małgorzata Smyczyńska \\ Hospicjum im. św. Łazarza w Krakowie
}

Epizod dwukrotnej defibrylacji u chorego z wszczepionym kardiowerterem-defibrylatorem (ICD, implantable cardioverter-defibrillator) umierającego z powodu zaawansowanego nowotworu oraz brak wytycznych postępowania w takich stanach w polskim piśmiennictwie skłoniły nas do podjęcia tego tematu. Wysoka skuteczność ICD w zapobieganiu nagłej śmierci sercowej maleje wraz ze zwiększaniem się liczby czynników ryzyka, a długotrwałe leczenie często (ok. 45\% pacjentów po 10 latach w badaniu polskim) wiąże się z powikłaniami. Pacjenci z ICD rzadko są obejmowani opieką paliatywną - zwykle wtedy, gdy chorobie serca towarzyszy zaawansowany nowotwór złośliwy.

Spośród około 1200 chorych leczonych rocznie w naszym ośrodku tylko kilka osób to pacjenci z ICD; z żadnym z nich nie przeprowadzono wcześniej rozmowy na temat spodziewanych korzyści i ryzyka defibrylacji u schyłku życia. Brak okresowej weryfikacji planu opieki medycznej powoduje, że nawet osoby bliskie śmierci czują się zabezpieczone „na wypadek zagrożenia życia”, nie dostrzegając ryzyka zwykle nieskutecznej defibrylacji w okresie agonii.

Dyskusje o możliwości dezaktywacji ICD w czasie kierowania do opieki hospicyjnej są trudne. Kardiolodzy zwykle nie czują się przygotowani do planowania wspólnie z chorym opieki medycznej końca życia, co w konsekwencji zwiększa później ryzyko podejmowania działań określanych jako daremne (nieprzynoszące korzyści) lub wręcz uporczywe (przedłużające umieranie i powodujące cierpienie lub naruszające godność). W okresie terminalnym chorób istnieją wskazania do odstąpienia od resuscytacji (w tym defibrylacji), tymczasem u co piątego pacjenta z ICD dochodzi do epizodu defibrylacji w ostatnich tygodniach życia - w 58\% hospicjów amerykańskich odnotowano przynajmniej jedną taką sytuację. Jeżeli według American Heart Association/ /European Society of Cardiology (AHA/ESC) od implantacji ICD należy odstąpić, gdy pacjent nie rokuje przeżycia roku w dobrym stanie funkcjonalnym, to tym bardziej w przypadku rozpoznania stanu terminalnego lekarz powinien rozważyć wyłączenie funkcji defibrylacji wszczepionego wcześniej urządzenia. Wybiórcza dezaktywacja ICD w okresie terminalnym nie oznacza wycofania się ze wszystkich metod leczniczych potencjalnie przedłużających życie choremu (nie zwalnia także z obowiązku dalszej opieki nad nim), jednak zapobiega uporczywej (bolesnej) terapii, jaką są traumatyczne próby ożywiania chorego, często w okresie jego agonii. Nawet skuteczna defibrylacja w takim stanie przywraca chorego jedynie do okresu umierania i tylko przedłuża ten proces. Wskazane byłoby zatem wcześniejsze zaplanowanie przeprogramowania ICD w celu wyłączenia funkcji defibrylacji z możliwością utrzymania ewentualnej prowadzonej dotychczas kardiostymulacji (czy leczenia resynchronizującego). Około 40\% pacjentów (w niedawnym badaniu czeskim) oczekiwało informacji dotyczących możliwości takiego przeprogramowania, a około połowa (w badaniu amerykańskim) akceptowała to postępowanie u kresu życia, zwłaszcza w obliczu cierpienia. W Stanach Zjednoczonych dezaktywację ICD uznaje się za jeden z mierników jakości życia w opiece paliatywnej, w Wielkiej Brytanii natomiast opracowano ostatnio specjalne wytyczne dla lekarzy dotyczące dezaktywacji. Planowanie wspólnie z chorym opieki medycznej końca życia w tym względzie wymaga jednak aktywnego współdziałania kardiologów i lekarzy medycyny paliatywnej.

W naszej opinii lekarz, rozpoznając stan terminalny u chorego z ICD (zwykle lekarz rodzinny lub opieki paliatywnej), powinien wspólnie z pacjentem rozważyć możliwość wybiórczej dezaktywacji urządzenia, uwzględniając korzyści i ryzyko oraz oczekiwania chorego. Następnie konsultujący kardiolog, do którego chory zostanie skierowany, powinien podjąć dalszą dyskusję z chorym, a w przypadku kompetentnie wyrażonego życzenia (formalnego wycofania zgody na kontynuację leczenia) - przeprogramować ICD. Takie postępowanie może spełnić oczekiwania chorych, obniżając ryzyko uporczywej terapii i cierpienia w końcowym okresie życia. 